\title{
HERMENÊUTICA CONSTITUCIONAL
}

Reis Friede*

Resumo: As normas constitucionais não possuem um exclusivo conteúdo jurídico, exatamente por se tratar a Constituição de um texto com nítida feição política, sendo válido concluir que os problemas de interpretação constitucional são mais amplos e complexos do que aqueles afetos à lei comum, razão pela qual a doutrina e a jurisprudência forjaram um arcabouço de métodos e princípios a serem manejados pelo exegeta quando da tarefa interpretativa do Texto Magno, tema que será abordado no presente artigo.

Palavras-chave: Hermenêutica Constitucional; Métodos de Interpretação; Princípios de Interpretação.

\section{CONSTITUTIONAL HERMENEUTICS}

Abstract: The constitutional norms do not possess an exclusive legal content, due mainly to the fact that the Constitution is a text with a clear political feature. Therefore, we must conclude that the constitutional interpretation problems are broader and more complex than those regarding the ordinary law, this being the reason why the doctrine and the jurisprudence forged a framework of methods and principles to be handled by the interpreter when analyzing the constitutional text, a subject which will be developed on the current article.

Keywords: Constitutional Hermeneutics; Interpretation Methods; Interpretation Principles.

\footnotetext{
* Reis Friede é Desembargador Federal. Mestre e Doutor em Direito e Professor e Pesquisador do Programa de Mestrado em Desenvolvimento Local do Centro Universitário Augusto Motta (UNISUAM). Correio eletrônico: reisfriede@hotmail.com.
} 


\section{INTRODUÇÃO}

O objetivo da denominada hermenêutica constitucional cinge-se ao estudo e à sistematização dos processos aplicáveis no âmbito da Constituição para determinar, sobretudo, o sentido e o alcance das normas constitucionais de conteúdo políticojurídico. Não obstante alguns autores entenderem como termos sinônimos, o vocábulo hermenêutica, em essência, distingue-se do termo interpretação. Hermenêutica é, em última análise, a ciência que fornece a técnica e, acima de tudo, os princípios basilares segundo os quais o operador do Direito (magistrados, membros do Ministério Público, advogados, defensores, delegados de polícia) poderá apreender o verdadeiro sentido (jurídico-político) da norma constitucional sob exame. Interpretação, por sua vez, consiste unicamente em desvendar o real significado do regramento normativo ínsito na Constituição, tema que será objeto do presente artigo.

\section{INTERPRETAÇÃO CONSTITUCIONAL}

Segundo Barroso (2011, p. 292), a interpretação jurídica "consiste na atividade de revelar ou atribuir sentido a textos ou outros elementos normativos (como princípios implícitos, costumes, precedentes), notadamente para o fim de solucionar problemas". Assim, toda e qualquer norma jurídica deve ser interpretada através dos critérios hermenêuticos que, em essência, possuem um relativo cunho de generalidade. Ocorre, entretanto, que as normas constitucionais, de forma diversa dos demais regramentos normativos, não possuem um exclusivo conteúdo jurídico, exatamente por se tratar a Constituição de um texto com nítida feição política, sendo válido concluir que os problemas de interpretação constitucional, em certa medida, são mais amplos e complexos do que aqueles afetos à lei comum, até mesmo porque, sob certa ótica, também repercutem sobre todo o ordenamento jurídico.

Os problemas da interpretação constitucional são mais amplos do que aqueles da lei comum, pois repercutem em todo o Ordenamento jurídico. Segundo HÉCTOR FIX-ZAMUDIO, a interpretação dos dispositivos constitucionais requer por parte do intérprete ou aplicador, particular sensibilidade que permite captar a essência, penetrar na profundidade e 
compreender a orientação das disposições fundamentais, tendo em conta as condições sociais, econômicas e políticas existentes no momento em que se pretende chegar ao sentido dos preceitos supremos [...]. Os diversos conceitos de Constituição, a natureza específica das disposições fundamentais que estabelecem regras de conduta de caráter supremo e que servem de fundamento e base para as outras normas do Ordenamento Jurídico, contribuem para as diferenças entre a interpretação jurídica ordinária e a constitucional. (OLIVEIRA, 1979, p. 54).

Por essa específica razão, a interpretação dos dispositivos constitucionais demanda um amplo conhecimento não só dos princípios norteadores da hermenêutica constitucional (na qualidade de autênticos princípios regentes do sistema de valoração político-jurídica do Texto Constitucional), assim como dos denominados preceitos constitucionais presentes no âmbito da normatização sistêmica da Constituição. Ademais, cumpre consignar que as regras básicas de interpretação das leis infraconstitucionais são igualmente fundamentais no deslinde da correta exegese do Texto Constitucional.

Para a boa interpretação constitucional é preciso verificar, no interior do sistema, quais as normas que foram prestigiadas pelo legislador constituinte ao ponto de convertê-las em princípios regentes desse sistema de valoração. Impende examinar como o Constituinte posicionou determinados preceitos constitucionais. Alcançada, exegeticamente, essa valoração, é que teremos os princípios. Estes, como assinala CELSO BANDEIRA DE MELLO, são mais do que normas, servindo como vetores para soluções interpretativas. De modo que é preciso, para tal, conhecer cada sistema normativo. No nosso, ressaltam o princípio federativo; o do voto direto, secreto, universal e periódico; a separação dos Poderes; os direitos e garantias individuais. Essa saliência é extraída do art. $60, \S 4^{\circ}$, do Texto Constitucional, que impede emenda tendente a abolir tais princípios. Por isso, a interpretação de uma norma constitucional levará em conta todo o sistema, tal como positivado, dando-se ênfase, porém, para os princípios que foram valorizados pelo Constituinte. Também não se pode deixar de verificar qual o sentido que o Constituinte atribui às palavras do texto constitucional, perquirição que só é possível pelo exame do todo normativo, após a correta apreensão da principiologia que ampara aquela palavra. (TEMER, 1989, p. 25-26).

De fato, a tarefa do intérprete é buscar o sentido e o alcance da norma jurídica expressa no texto legal que a veicula. Para tanto, é necessário que seja reconstituído o pensamento legislativo de forma objetiva, desapaixonada e equilibrada, cabendo ao intérprete manter-se sempre fiel à essência da lei.

Interpretar não é declarar o sentido histórico já inexistente na lei, mas aquilo que seja imanente e vivo, muitas vezes expresso em metáforas, que se esclarece à 
medida que é colocado em conexão com outras normas. Na interpretação, o jurista deve ter sempre em mente o resultado prático que a lei visa atingir e os próprios princípios constitucionais fundamentais. Decerto, o objetivo da interpretação da lei é exatamente o de desentranhar o sentido atual da norma jurídica, que nem sempre será o mesmo da época em que a lei foi promulgada. Todavia, tal ato interpretativo não pode ser levado a extremos, chegando ao cúmulo de transformar o intérprete em legislador, sem a necessária legitimidade. De qualquer forma, a interpretação constitucional, particularizada no universo da interpretação jurídica, engloba uma série de métodos e princípios, os quais serão tratados nos itens seguintes.

\section{MÉTODOS DE INTERPRETAÇÃO CONSTITUCIONAL}

Por interpretação das normas constitucionais, segundo Canotilho (1993, p. 212-213), entende-se o arcabouço de métodos elaborados pela doutrina e pela jurisprudência com base em critérios ou premissas (filosóficas, metodológicas, epistemológicas) diferentes, mas que, de um modo geral, revelam-se reciprocamente complementares, o que ressalta a natureza unitária da tarefa interpretativa. De acordo com a melhor doutrina sobre o assunto, os métodos empregados quando da exegese constitucional são os seguintes: método jurídico ou hermenêutico clássico, método tópico-problemático, método hermenêutico concretizador, método científicoespiritual, método normativo-estruturante e método da comparação constitucional.

\subsection{Método Jurídico ou Hermenêutico Clássico}

Segundo o método sob exame, a Constituição, malgrado o status hierárquico (e supremo) por ela ocupado no ordenamento jurídico, deve ser concebida como uma verdadeira lei, devendo receber, por conseguinte, a incidência dos métodos interpretativos clássicos, a saber: gramatical (literal ou filológico), racional (ou lógico), sistemático, histórico, teleológico (ou sociológico). 
Conforme explicam Mendes, Celho e Branco (2010, p. 161), a missão do intérprete seria, a partir do manejo dos referidos métodos, descobrir o verdadeiro significado das normas constitucionais.

\subsection{Método Tópico-Problemático}

O método tópico-problemático desenvolve-se a partir de uma premissa básica, qual seja, a que concebe a Constituição como um sistema aberto de regras e princípios, possibilitando, assim, diversas interpretações a respeito do Texto Constitucional, notadamente por ser este composto por normas polissêmicas.

A principal característica do método em comento reside no seu caráter prático, isto é, o intérprete, na busca por uma solução, parte do problema para a norma, conferindo à interpretação um viés eminentemente prático.

\subsection{Método Hermenêutico Concretizador}

Lenza discorrendo sobre o método em questão, aduz que:

Diferente do método tópico-problemático, que parte do caso concreto para a norma, o método hermenêutico-concretizador parte da Constituição para o problema, destacando-se os seguintes pressupostos interpretativos: pressupostos subjetivos: o intérprete vale-se de suas pré-compreensões sobre o tema para obter o sentido da norma; pressupostos objetivos: o intérprete atua como mediador entre a norma e a situação concreta, tendo como 'pano de fundo' a realidade social; círculo hermenêutico: é o 'movimento de ir e vir' do subjetivo para o objetivo, até que o intérprete chegue a uma compreensão da norma. $O$ fato de se partir das précompreensões do intérprete pode distorcer não somente a realidade, como também o próprio sentido da norma. (LENZA, 2012, p. 154).

\subsection{Método Científico-Espiritual}

O modelo científico-espiritual considera a Constituição como um autêntico instrumento de integração (em sentido amplo), isto é, não a concebe somente sob a ótica jurídico-formal (a Lei Maior enquanto fundamento de validade de todo o ordenamento jurídico), mas, igual e principalmente, sob o enfoque políticosociológico, vale dizer, como instrumento de construção, ordenação e preservação do 
tecido social, razão pela a Constituição deve ser interpretada de modo extensivo e flexível. A propósito, lecionam Mendes, Coelho e Branco:

Sendo o Direito Constitucional uma positivação das possibilidades e funções próprias do mundo do espírito - um conjunto de normas que só se compreendem como referência a essas mesmas realidades espirituais, as quais, por seu turno, só se realizam, de forma plena e continuada, por força dessa positivação, que Ihes confere normatividade -, por tudo isso, não deve o intérprete encarar a Constituição como um momento estático e permanente. (MENDES; COELHO; BRANCO, 2010, p. 165).

A partir da lição de Mendes, Coelho e Branco, pode-se inferir que tal método confere relevância não à literalidade do texto, mas, sim, à realidade social e aos valores subjacentes ao Texto Magno.

\subsection{Método Normativo-Estruturante}

Para o perfeito entendimento do método em questão, cumpre transcrever os ensinamentos de Canotilho a respeito da teoria estruturante, de Friedrich Müller:

Elemento decisivo para a compreensão da estrutura normativa é uma teoria hermenêutica da norma jurídica que arranca da não identidade entre norma e texto normativo; o texto de um preceito jurídico positivo é apenas a parte descoberta do iceberg normativo (F. MÜLLER), correspondendo em geral ao programa normativo (ordem ou comando jurídico na doutrina tradicional); mas a norma não compreende apenas o texto, antes abrange um 'domínio normativo', isto é, um 'pedaço de realidade social' que o programa normativo só parcialmente contempla; consequentemente, a concretização normativa deve considerar e trabalhar com dois tipos de concretização: um formado pelos elementos resultantes da interpretação do texto da norma (= elemento literal da doutrina clássica); outro, o elemento de concretização resultante da investigação do referente normativo (domínio ou região normativa). (CANOTILHO, 2003, p. 1213).

Eros Grau, explanando sobre o processo formulado por Müller, propõe as seguintes etapas quando da tarefa interpretativa:

Inicialmente caminhamos do texto da norma até a norma jurídica. Em seguida caminhamos da norma jurídica até a norma de decisão, aquela que determina a solução do caso. Apenas então se dá a concretização da norma, ou seja, mediante a produção de uma norma jurídica geral, no quadro da solução de um caso determinado. (GRAU, 2005, p. 73). 
Conforme explicado por Canotilho, Müller reconhece a inexistência de identidade entre norma e texto normativo, sendo este apenas a ponta do iceberg normativo, razão pela qual, segundo o método em tela, o intérprete deve levar em consideração outros fatores, além do Texto Constitucional, no momento de interpretar. Para tanto, deve seguir as seguintes fases, assim anotadas por Schier:

O primeiro momento - existência e averiguação semântica do texto e interpretação do texto com a respectiva atribuição de sentidos - resulta no chamado programa normativo; o segundo momento - existência e averiguação da componente fática, real, empírica (o problema posto a resolver) e interpretação dessa realidade fática - resulta no chamado domínio normativo e, por fim, da contextualização do programa normativo e domínio normativo, obtém-se a norma. A norma, aqui, seria, portanto, não o ponto de partida da interpretação e, sim, o produto final desta atividade. (SCHIER, 1999, p. 119-120).

\subsection{Método da Comparação Constitucional}

Häberle (2001, p. 164) postula a "canonização" da comparação entre os vários ordenamentos constitucionais como mais um dos métodos de interpretação, além daqueles (métodos ou elementos) tradicionais desenvolvidos por SAVIGNY (gramatical, lógico, histórico e sistemático). É deste modo que o método comparativo constitucional, aliando os métodos gramatical, lógico, histórico e sistemático ao Direito Comparado, objetiva buscar, nos diversos ordenamentos jurídicos existentes, a melhor direção interpretativa das normas constitucionais de um Estado.

\section{PRINCÍPIOS DE INTERPRETAÇÃO CONSTITUCIONAL}

A doutrina e a jurisprudência aludem, ainda, aos seguintes princípios de interpretação: princípio da unidade da Constituição, princípio da concordância prática ou harmonização, princípio do efeito integrador, princípio da força normativa, princípio da máxima efetividade ou eficiência e princípio da justeza ou da conformidade (exatidão ou correção) funcional. 


\subsection{Princípio da Unidade da Constituição}

O princípio da unidade da Constituição, como a própria denominação sugere, preconiza que os dispositivos constitucionais devem ser analisados não de forma isolada, mas enquanto integrantes de um dado sistema unitário de regras e princípios. Demonstrando a aplicação concreta do princípio em epígrafe, transcrevese o seguinte julgado do Supremo Tribunal Federal:

Os postulados que informam a teoria do Ordenamento Jurídico e que the dão 0 necessário substrato doutrinário assentam-se na premissa fundamental de que o sistema de Direito Positivo, além de caracterizar uma unidade institucional, constitui um complexo de normas que devem manter entre si um vínculo de essencial coerência.

O Ato das Disposições Transitórias, promulgado em 1988 pelo legislador constituinte, qualifica-se, juridicamente, como um estatuto de índole constitucional. A estrutura normativa que nele se acha consubstanciada ostenta, em consequência, a rigidez peculiar às regras inscritas no texto básico da Lei Fundamental da República. Disso decorre o reconhecimento de que inexistem, entre as normas inscritas no ADCT e os preceitos constantes da Carta Política, quaisquer desníveis ou desigualdades quanto à intensidade de sua eficácia ou à prevalência de sua autoridade. Situam-se, ambos, no mais elevado grau de positividade jurídica, impondo-se, no plano do ordenamento estatal, enquanto categorias normativas subordinantes, à observância compulsória de todos, especialmente dos órgãos que integram o aparelho de Estado.

Inexiste qualquer relação de antinomia real ou insuperável entre a norma inscrita no art. 33 do ADCT e os postulados da isonomia, da justa indenização, do direito adquirido e do pagamento mediante precatórios, consagrados pelas disposições permanentes da Constituição da República, eis que todas essas cláusulas normativas, inclusive aquelas de índole transitória, ostentam grau idêntico de eficácia e de autoridade jurídicas.

O preceito consubstanciado no art. 33 do ADCT - somente inaplicável aos créditos de natureza alimentar - compreende todos os precatórios judiciais pendentes de pagamento em 05.10 .88 , inclusive aqueles relativos a valores decorrentes de desapropriações efetivadas pelo Poder Público. (BRASIL, 1994a, p. 1).

Da leitura do julgado acima nota-se que a Corte Suprema, com base no princípio da unidade da Constituição, afastou a existência de qualquer hierarquia entre as normas que integram o Ato das Disposições Constitucionais Transitórias $(A D C T)$ e as que se encontram no corpo do Texto Magno. 


\subsection{Princípio da Concordância Prática ou Harmonização}

Objetiva-se, através princípio da concordância prática, harmonizar os bens jurídicos constitucionalmente tutelados, evitando-se, diante de eventual situação de conflito, o sacrifício de um deles. Com efeito, deve o intérprete, em casos assim, buscar uma solução que viabilize a realização de todos os bens jurídicos envolvidos e, ao mesmo tempo, adotar uma postura interpretativa que não acarrete a negação de nenhum deles.

\subsection{Princípio do Efeito Integrador}

Segundo o princípio do efeito integrador, quando da resolução de problemas jurídico-constitucionais, o operador do Direito deve priorizar soluções que conduzam à integração social e à unidade política. Afinal, a Constituição, além de estabelecer uma determinada ordem jurídica, necessita produzir e manter a coesão sociopolítica, enquanto autêntico pré-requisito ou mesmo condição de viabilidade de qualquer sistema jurídico (MENDES; COELHO; BRANCO, 2010, p. 178).

\subsection{Princípio da Força Normativa}

De acordo com a ideia central contida no princípio da força normativa, deve-se conferir às normas constitucionais, quando da solução de problemas, a máxima aplicação e efetivação. Com base em tal raciocínio, a Suprema Corte tem empregado o princípio em questão em suas decisões, mormente para afastar interpretações divergentes da Constituição, evitando-se, deste modo, o enfraquecimento de sua força normativa, exatamente a conclusão obtida quando do julgamento do Recurso Extraordinário no 560.626/RS, relatado pelo Min. Gilmar Mendes:

I. As normas relativas à prescrição e à decadência tributárias têm natureza de normas gerais de Direito Tributário, cuja disciplina é reservada à lei complementar, tanto sob a Constituição pretérita (art. 18, § 10, da CF de 1967/69) quanto sob a Constituição atual (art. 146, III, b, da CF de 1988). Interpretação que preserva a força normativa da Constituição, que prevê 
disciplina homogênea, em âmbito nacional, da prescrição, decadência, obrigação e crédito tributários. Permitir regulação distinta sobre esses temas, pelos diversos entes da federação, implicaria prejuízo à vedação de tratamento desigual entre contribuintes em situação equivalente e à segurança jurídica.

II. O Código Tributário Nacional (Lei 5.172/1966), promulgado como lei ordinária e recebido como lei complementar pelas Constituições de 1967/69 e 1988, disciplina a prescrição e a decadência tributárias.

III. As contribuições, inclusive as previdenciárias, têm natureza tributária e se submetem ao regime jurídico-tributário previsto na Constituição. Interpretação do art. 149 da CF de 1988. Precedentes.

IV. Inconstitucionalidade dos arts. 45 e 46 da Lei 8.212/91, por violação do art. 146, III, b, da Constituição de 1988 , e do parágrafo único do art. $5^{\circ}$ do Decreto-lei 1.569/77, em face do $\S 11^{0}$ do art. 18 da Constituição de $1967 / 69$.

V. São legítimos os recolhimentos efetuados nos prazos previstos nos arts. 45 e 46 da Lei 8.212/91 e não impugnados antes da data de conclusão deste julgamento. (BRASIL, 2008a, p. 1).

Em outra ocasião, o Pretório Excelso entendeu que a "manutenção de decisões das instâncias ordinárias divergentes da interpretação adotada pelo STF revela-se afrontosa à força normativa da Constituição e ao princípio da máxima efetividade da norma constitucional." (BRASIL, 2008b, não paginado).

\subsection{Princípio da Máxima Efetividade ou Eficiência}

Sobre o princípio em tela, discorre o professor Canotilho:

É um princípio operativo em relação a todas e quaisquer normas constitucionais, e embora a sua origem esteja ligada à tese da actualidade das normas programáticas ( Thoma), é hoje sobretudo invocado no âmbito dos direitos fundamentais (no caso de dúvidas deve preferir-se a interpretação que reconheça maior eficácia aos direitos fundamentais). (CANOTILHO, 2003, p. 1.224).

Amparada no aludido princípio, a Primeira Turma do Supremo Tribunal Federal, Agravo Regimental no Recurso em Habeas Corpus no 124.137/BA decidiu que "o art. 400 do Código de Processo Penal, com a redação dada pela Lei no 11.719/2008, fixou o interrogatório do réu como ato derradeiro da instrução penal, prestigiando a máxima efetividade das garantias constitucionais do contraditório e da ampla defesa (art. 50, LV, CF), dimensões elementares do devido processo legal (art. 50, LIV, CF) e cânones essenciais do Estado Democrático de Direito (art. 10, caput, CF)", razão pela qual o mencionado dispositivo do Código de Processo Penal comum 
deve ser igualmente observado no âmbito do processo penal militar, em detrimento da norma específica prevista no art. 302 do Decreto-Lei no 1.002/69, Código de Processo Penal Militar. (BRASIL, 2016a, p. 1).

\subsection{Princípios da Justeza ou da Conformidade (Exatidão ou Correção) Funcional}

Segundo preconiza Novelino (2009, p. 79), o princípio em questão "atua no sentido de impedir que os órgãos encarregados da interpretação da Constituição, sobretudo o Tribunal Constitucional, cheguem a um resultado contrário ao esquema organizatório-funcional estabelecido por ela", razão pela qual ao Supremo Tribunal Federal é vedado promover modificações quanto à sistemática de repartição de funções fixadas pelo próprio Texto Magno.

\subsection{Princípio da Interpretação conforme a Constituição}

O princípio da interpretação conforme a Constituição informa que, existindo várias interpretações possíveis para o texto jurídico impugnado, deve-se prestigiar aquela que esteja em consonância com a Carta da República, destacando, assim, o princípio da supremacia constitucional, de modo a afastar uma exegese contrária à Lei Magna. Na realidade, segundo a doutrina amplamente majoritária, tal figura não se resume a um simples princípio de interpretação constitucional. De fato, a interpretação conforme a Constituição encontra fundamento na presunção de que as leis, de um modo geral, são constitucionais. Significa dizer que, na dúvida, deve-se optar por uma diç̧ão que seja coerente com a Carta da República. Da mesma forma, objetiva-se, a partir de tal princípio, viabilizar a manutenção do texto legal tido (inicialmente) por ofensivo à Constituição, conferindo-Ihe um significado compatível com a Lei Magna.

Neste sentido, assevera o Ministro Gilmar Mendes que o Supremo Tribunal Federal, ao adotar "uma interpretação conforme à Constituição, restringindo o significado de certa expressão literal ou colmatando uma lacuna contida no regramento ordinário", não procede de modo a afirmar "propriamente a ilegitimidade 
da lei, limitando-se a ressaltar que uma dada interpretação é compatível com a Constituição, ou, ainda, que, para ser considerada constitucional, determinada norma necessita de um complemento (lacuna aberta) ou restrição (lacuna oculta - redução teleológica)." (BRASIL, 2014a, p. 18).

Evita-se, desta feita, sua expulsão do âmbito do ordenamento jurídico, bem como as respectivas consequências jurídicas dela advindas. Afirma-se, ademais, que o emprego do princípio sob exame homenageia o modelo da separação dos poderes, uma vez que, por meio dele, o Poder Judiciário aproveita o texto legal elaborado pelo Poder Legislativo, dando-Ihe uma interpretação condizente com a Constituição.

Trata-se, de qualquer forma, de um princípio que deve ser utilizado com o devido cuidado, mormente diante da impossibilidade de o Judiciário se transformar em legislador positivo, conforme assentado, inclusive, na jurisprudência do próprio Supremo, na Medida Cautelar na Ação Direta de Inconstitucionalidade nº 1.063/DF, "a ação direta de inconstitucionalidade não pode ser utilizada com o objetivo de transformar o STF, indevidamente, em legislador positivo, eis que o poder de inovar o sistema normativo, em caráter inaugural, constitui função típica da instituição parlamentar." (BRASIL, 1994b, p. 4).

Assim, ante a existência de normas infraconstitucionais dotadas de vários significados possíveis, deve o exegeta preferir a interpretação que Ihes confira um sentido compatível com a Constituição, preservando, por conseguinte, a autoridade do comando normativo e o princípio da separação dos poderes (NOVELINO, 2009, p. 75). A título de exemplo, o Pleno do Supremo Tribunal Federal, ao julgar a Ação Direta de Inconstitucionalidade no 4.203/RJ, Rel. Min. Dias Toffoli, julgamento em 30.10.2014, conferiu interpretação conforme a Constituição ao art. $5^{\circ}$ da Lei $n^{\circ}$ 5.388/99, do Estado do Rio de Janeiro, para que a obrigação nele contida (entrega de declaração de bens, por agentes públicos estaduais, à Assembleia Legislativa) somente seja imposta aos administradores ou responsáveis por bens e valores públicos ligados ao Poder Legislativo. (BRASIL, 2014b).

Discorrendo sobre o assunto em questão, Lenza (2012, p. 158-159) adverte que o manejo do aludido princípio requer a observância dos seguintes aspectos fundamentais: a) "prevalência da Constituição: deve-se preferir a interpretação não 
contrária à Constituição"; b) "conservação de normas: percebendo o intérprete que uma lei pode ser interpretada em conformidade com a Constituição, ele deve assim aplicá-la para evitar a sua não continuidade"; c) "exclusão da interpretação contra legem: o intérprete não pode contrariar o texto literal e o sentido da norma para obter a sua concordância com a Constituição"; d) "espaço de interpretação: só se admite a interpretação conforme a Constituição se existir um espaço de decisão e, dentre as várias que se chegar, deverá ser aplicada aquela em conformidade com a Constituição"; e) "rejeição ou não aplicação de normas inconstitucionais: uma vez realizada a interpretação da norma, pelos vários métodos, se o juiz chegar a um resultado contrário à Constituição, em realidade, deverá declarar a inconstitucionalidade da norma, proibindo a sua correção contra a Constituição"; f) "o intérprete não pode atuar como legislador positivo: não se aceita a interpretação conforme a Constituição quando, pelo processo de hermenêutica, se obtiver uma regra nova e distinta daquela objetivada pelo legislador e com ela contraditória, em seu sentido literal ou objetivo. Deve-se, portanto, afastar qualquer interpretação em contradição com os objetivos pretendidos pelo legislador".

\subsection{Princípio da Proporcionalidade ou Razoabilidade}

Segundo Coelho (2007, p. 109), o princípio ora analisado, "em essência, consubstancia uma pauta de natureza axiológica que emana diretamente das ideias de justiça, equidade, bom senso, prudência, moderação, justa medida, proibição de excesso, direito justo e valores afins".

Cumpre acrescentar, no referido catálogo axiológico anotado pelo citado autor, a denominada proibição de insuficiência. Assim, além da aludida proibição de excesso, admite-se a incidência do princípio da proporcionalidade não apenas como instrumento de controle contra eventuais excessos do Estado, mas, igualmente, como mecanismo contra a proteção estatal insuficiente, de modo a tutelar as denominadas liberdades positivas, isto é, aquelas que demandam do Estado não uma conduta omissiva, mas, em contraste, uma atuação positiva. A propósito, confira-se o julgado no Habeas Corpus 104.410/RS, abaixo: 
Mandatos Constitucionais de Criminalização: A Constituição de 1988 contém um significativo elenco de normas que, em princípio, não outorgam direitos, mas que, antes, determinam a criminalização de condutas (CF, art. 50, XLI, XLII, XLIII, XLIV; art. 70, X; art. 227, § 40). Em todas essas normas é possível identificar um mandato de criminalização expresso, tendo em vista os bens e valores envolvidos. Os direitos fundamentais não podem ser considerados apenas como proibições de intervenção (Eingriffsverbote), expressando também um postulado de proteção (Schutzgebote). Pode-se dizer que os direitos fundamentais expressam não apenas uma proibição do excesso (Übermassverbote), como também podem ser traduzidos como proibições de proteção insuficiente ou imperativos de tutela (Untermassverbote). Os mandatos constitucionais de criminalização, portanto, impõem ao legislador, para o seu devido cumprimento, o dever de observância do princípio da proporcionalidade como proibição de excesso e como proibição de proteção insuficiente. (BRASIL, 2012, p. 1).

Depreende-se do julgado acima que o princípio da proporcionalidade tem sido largamente empregado no que se refere à proteção dos direitos fundamentais, conforme explica, inclusive, o Ministro Gilmar Mendes, segundo o qual a aplicação do aludido princípio ocorre, por exemplo, quando se verifica uma "restrição a determinado direito fundamental ou um conflito entre distintos princípios constitucionais, de modo a exigir que se estabeleça o peso relativo de cada um dos direitos por meio da aplicação das máximas que integram o mencionado princípio da proporcionalidade", raciocínio que, consoante leciona Gilmar Mendes, na Ação Direta de Inconstitucionalidade no 5.136/DF, opera-se da seguinte forma:

Tal como já sustentei em estudo sobre a proporcionalidade na jurisprudência do Supremo Tribunal Federal, há de perquirir-se se em face do conflito entre dois bens constitucionais contrapostos, o ato impugnado afigura-se adequado, isto é, apto para produzir o resultado desejado; necessário, isto é, insubstituível por outro meio menos gravoso e igualmente eficaz; e proporcional em sentido estrito, ou seja, se estabelece uma relação ponderada entre o grau de restrição de um princípio e o grau de realização do princípio contraposto. (BRASIL, 2014c, p. 2).

A transcrita jurisprudência da Corte Magna revela que a noção de proporcionalidade, além de ser um método racional para solucionar conflitos entre direitos fundamentais, abarca a análise de seus elementos constitutivos (adequação, necessidade e proporcionalidade em sentido estrito), em relação aos quais, registre-se, não há consenso doutrinário, havendo as seguintes posições quanto ao número exigido: (dois elementos: adequação e necessidade), (três elementos: adequação, necessidade e proporcionalidade em sentido estrito) e (quatro elementos: pressuposto teleológico de legitimidade dos fins 


\section{perseguidos, adequação, necessidade e proporcionalidade em sentido estrito).}

Entendendo-se como correta a estrutura que abarca três elementos, o operador do Direito deverá, em primeiro lugar, analisar a adequação da medida, isto é, se a mesma é apta a produzir o resultado desejado. Em seguida, refletirá quanto à sua necessidade, vale dizer, se se trata, entre as medidas adequadas, do meio menos gravoso para se atingir o fim. Por fim, fará uma ponderação entre a intensidade da restrição promovida com o meio e a importância do atingimento do fim (proporcionalidade em sentido estrito).

A título de exemplo, cabe registrar que o Ministro Luís Roberto Barroso, quando de seu voto-vista no Habeas Corpus no 124.306/RJ, julgamento em 29.11.2016, no qual se discutiu a constitucionalidade da criminalização do aborto, cogitou a respeito do princípio da proporcionalidade, desenvolvendo o seguinte raciocínio:

\section{Violação ao princípio da proporcionalidade.}

33. O legislador, com fundamento e nos limites da Constituição, tem liberdade de conformação para definir crimes e penas. Ao fazê-lo, deverá ter em conta dois vetores essenciais: o respeito aos direitos fundamentais dos acusados, tanto no plano material como no processual; e os deveres de proteção para com a sociedade, cabendo-Ihe resguardar valores, bens e direitos fundamentais dos seus integrantes. Nesse ambiente, o princípio da razoabilidade-proporcionalidade, além de critério de aferição da validade das restrições a direitos fundamentais, funciona também na dupla dimensão de proibição do excesso e da insuficiência.

34. Cabe acrescentar, ainda, que o Código Penal brasileiro data de 1940. E, a despeito de inúmeras atualizações ao longo dos anos, em relação aos crimes aqui versados - arts. 124 a 128 - ele conserva a mesma redação. $[\ldots]$.

35. [...] na linha do que foi exposto acerca dos três subprincípios que dão conteúdo à proporcionalidade, a tipificação penal nesse caso somente estará então justificada se: (i) for adequada à tutela do direito à vida do feto (adequação); (ii) não houver outro meio que proteja igualmente esse bem jurídico e que seja menos restritivo dos direitos das mulheres (necessidade); e (iii) a tipificação se justificar a partir da análise de seus custos e benefícios (proporcionalidade em sentido estrito).

\subsection{Subprincípio da adequação}

35. Em relação à adequação, é preciso analisar se e em que medida a criminalização protege a vida do feto. [...].

39. [...] a criminalização do aborto não é capaz de evitar a interrupção da gestação e, logo, é medida de duvidosa adequação para a tutela da vida do feto. É preciso reconhecer, como fez o Tribunal Federal Alemão, que, considerando 'o sigilo relativo ao nascituro, sua impotência e sua dependência e ligação única com a mãe, as chances do Estado de protegê-lo 
serão maiores se trabalhar em conjunto com a mãe', e não tratando a mulher que deseja abortar como uma criminosa.

2.2. Subprincípio da necessidade

40. Em relação à necessidade, é preciso verificar se há meio alternativo à criminalização que proteja igualmente o direito à vida do nascituro, mas que produza menor restrição aos direitos das mulheres. Como visto, a criminalização do aborto viola a autonomia, a integridade física e psíquica e os direitos sexuais e reprodutivos da mulher, a igualdade de gênero, e produz impacto discriminatório sobre as mulheres pobres.

41. Nesse ponto, ainda que se pudesse atribuir uma mínima eficácia ao uso do direito penal como forma de evitar a interrupção da gestação, deve-se reconhecer que há outros instrumentos que são eficazes à proteção dos direitos do feto e, simultaneamente, menos lesivas aos direitos da mulher. $[\ldots]$.

2.3. Subprincípio da proporcionalidade em sentido estrito

43. Por fim, em relação à proporcionalidade em sentido estrito, é preciso verificar se as restrições aos direitos fundamentais das mulheres decorrentes da criminalização são ou não compensadas pela proteção à vida do feto. [...]. (BRASIL, 2016b, p. 13-17).

No referido Habeas Corpus, a Primeira Turma do Supremo, aplicando o princípio da proporcionalidade, estabeleceu um limite à atuação estatal (mormente no que concerne ao poder de criminalizar determinados comportamentos), entendendo que a restrição estabelecida no Código Penal quanto à prática abortiva antes do terceiro mês de gestação não encontra acolhida junto ao Texto Constitucional.

Ademais, conforme já decidiu a Corte Magna, na Ação Direta de Inconstitucionalidade no 2.551/MG, "o princípio da proporcionalidade acha-se vocacionado a inibir e a neutralizar os abusos do Poder Público no exercício de suas funções, qualificando-se como parâmetro de aferição da própria constitucionalidade material dos atos estatais." (BRASIL, 2003, p. 3).

\section{CONCLUSÃO}

Conforme consignado, as normas constitucionais, de forma diversa dos demais regramentos normativos, não possuem um exclusivo conteúdo jurídico, exatamente por se tratar a Constituição de um texto com nítida feição política, sendo válido concluir que os problemas de interpretação constitucional, em certa medida, são mais amplos e complexos do que aqueles afetos à lei comum, razão pela qual a doutrina e a jurisprudência forjaram um arcabouço de métodos (método jurídico ou 
hermenêutico clássico, método tópico-problemático, método hermenêutico concretizador, método científico-espiritual, método normativo-estruturante e método da comparação constitucional) e princípios (princípio da unidade da Constituição, princípio da concordância prática ou harmonização, princípio do efeito integrador, princípio da força normativa, princípio da máxima efetividade ou eficiência e princípio da justeza ou da conformidade) a serem manejados pelo exegeta quando da tarefa interpretativa do Texto Magno.

\section{REFERÊNCIAS}

BARROSO, Luís Roberto. Curso de Direito Constitucional Contemporâneo: os Conceitos Fundamentais e a Construção do Novo Modelo. 3. ed. São Paulo: Saraiva, 2011.

BRASIL. Supremo Tribunal Federal (Tribunal Pleno). Ação Direta de Inconstitucionalidade $n^{\circ}$ 4.203/RJ. Lei no 5.388/99 do Estado do Rio de Janeiro. CONAMP. Obrigação de entrega de declaração de bens à Assembleia Legislativa por agentes públicos estaduais. Competência atribuída ao Poder Legislativo sem o devido amparo constitucional. Vício de iniciativa. Parcial procedência. Requerente: Associação Nacional dos Membros do Ministério Público CONAMP. Intimado: Assembléia Legislativa do Estado do Rio de Janeiro. Relator: Min. Dias Toffoli, 30 de outubro de 2014b. Disponível em:

http://redir.stf.jus.br/paginadorpub/paginador.jsp?docTP=TP\&docID $=7645033$. Acesso em: 31 de mar. 2020.

BRASIL. Supremo Tribunal Federal (1. Turma). Agravo Regimental no Recurso em Habeas Corpus n⿳ 124.137/BA. Agravo regimental no recurso ordinário em habeas corpus. Penal e processual penal militar. Agressão a superior hierárquico. Agravante: Ministério Público Federal. Agravado: Itamar Silva Moreno Relator: Min. Luiz Fux, 17 de maio de 2016a. Disponível em: http://redir.stf.jus.br/paginadorpub/paginador.jsp?docTP=TP\&docID=11064728. Acesso em: 14 mar. 2020.

BRASIL. Supremo Tribunal Federal (1. Turma). Agravo Regimental no Recurso Extraordinário n⿳0 160.486/SP. Precatório - Pagamento parcelado - ADCT, Art. 33 - Natureza Jurídica das normas integrantes do ADCT. Agravante: Município de Santos. Agravado: Santos e Ferreira LTDA. Relator: Min. Celso de Mello, 11 de outubro 1994a. Disponível em:

http://redir.stf.jus.br/paginadorpub/paginador.jsp?docTP=AC\&docID=213448. Acesso em: 10 mar. 2020. 
BRASIL. Supremo Tribunal Federal (2. Turma). Habeas Corpus nº 104.410/RS. Porte ilegal de arma de fogo desmuniciada. (A)Tipicidade da conduta. Controle de constitucionalidade das leis penais. Paciente: Aldori Lima ou Aldori de Lima. Impetrante: Defensoria Pública da União. Relator: Min. Gilmar Mendes, 6 de março de 2012. Disponível em:

http://redir.stf.jus.br/paginadorpub/paginador.jsp?docTP=TP\&docID $=1851040$. Acesso em: 15 mar. 2020.

BRASIL. Supremo Tribunal Federal (1. Turma). Habeas Corpus nº 124.306/RJ. Direito processual penal. Habeas corpus. Prisão preventiva. Ausência dos requisitos para sua decretação. Inconstitucionalidade da incidência do tipo penal do aborto no caso de interrupção voluntária da gestação no primeiro trimestre ordem concedida de ofício. Pacientes: Edilson dos Santos; Rosemre Aparecida Ferreira. Impetrante: Jair Leite Pereira. Relator: Min. Marco Aurélio, 29 de novembro de 2016b. Disponível em: http://redir.stf.jus.br/paginadorpub/paginador.jsp?docTP=TP\&docID=12580345. Acesso em: 14 mar. 2020.

BRASIL. Supremo Tribunal Federal (Tribunal Pleno). Medida Cautelar na Ação Direta de Inconstitucionalidade n⿳0 1.063/DF. Lei no 8.713/93 - Processo eleitoral de 1994. Requerente: Partido social Cristão. Requeridos: Presidente da República; Congresso Nacional. Relator: Min. Celso de Mello, 18 de maio de 1994b. Disponível em:

http://redir.stf.jus.br/paginadorpub/paginador.jsp?docTP=TP\&docID=7026467. Acesso em: 15 mar. 2020.

BRASIL. Supremo Tribunal Federal (Tribunal Pleno). Medida Cautelar na Ação Direta de Inconstitucionalidade $\mathbf{n}^{\circ}$ 2.551/MG. Taxa de expediente do Estado de Minas Gerais - DPVAT - Incidência da referida taxa sobre as sociedades seguradas. Requerente: Confederação Nacional do Comércio e outra. Requerida: Assembleia Legislativa do Estado de Minas Gerais. Relator: Min. Celso de Mello, 2 de abril de 2003. Disponível em:

http://redir.stf.jus.br/paginadorpub/paginador.jsp?docTP=AC\&docID=266148. Acesso em: 14 mar. 2020.

BRASIL. Supremo Tribunal Federal (Tribunal Pleno). Medida Cautelar na Ação Direta de Inconstitucionalidade no 5.136/DF. Violação da liberdade de expressão. Inexistência. Aplicação do princípio da proporcionalidade. Juízo de ponderação do legislador para limitar manifestações que tenderiam a gerar maiores conflitos e atentar contra a segurança dos participantes de evento de grande porte. Medida cautelar indeferida. Ação julgada improcedente. Requerente: Partido da Social Democracia Brasileira - PSDB. Intimados: Presidente da República; Congresso Nacional. Relator: Min. Gilmar Mendes, julgamento em 1 de julho de 2014c. Disponível em: http://redir.stf.jus.br/paginadorpub/paginador.jsp?docTP=TP\&docID=7088799. Acesso em: 16 mar. 2020. 
BRASIL. Supremo Tribunal Federal (Tribunal Pleno). Reclamação no 4.335/AC. Progressão de regime. Crimes hediondos. Decisão reclamada aplicou o art. $2^{\circ}, \S 20$, da Lei no 8.072/90, declarado inconstitucional pelo Plenário do STF no HC 82.959/SP, Rel. Min. Marco Aurélio, DJ 1.9.2006. Reclamante: Defensoria Pública da União. Reclamado: Juiz de Direito da Vara de Execuções Penais da Comarca de Rio Branco. Relator: Min. Gilmar Mendes, julgamento em 20 de março de 2014a. Disponível em: http://redir.stf.jus.br/paginadorpub/paginador.jsp?docTP=AC\&docID=630101. Acesso em: 15 mar. 2020.

BRASIL. Supremo Tribunal Federal (Tribunal Pleno). Recurso Extraordinário no 328.812/AM. Reajustes de Remuneração, Proventos ou Pensão. Recorrente: Instituto Nacional do Seguro Social - INSS. Recorrido: Maria Auxiliadora Santos Cabral dos Anjos. Relator: Min. Gilmar Mendes, 6 de março de 2008b. Disponível em: http://portal.stf.jus.br/processos/detalhe.asp?incidente=1978185. Acesso em: 12 mar. 2020.

BRASIL. Supremo Tribunal Federal (Tribunal Pleno). Recurso Extraordinário no $\mathbf{5 6 0 . 6 2 6 / R S . ~ P r e s c r i c ̧ a ̃ o ~ e ~ d e c a d e ̂ n c i a ~ t r i b u t a ́ r i a s . ~ M a t e ́ r i a s ~ r e s e r v a d a s ~ a ~ l e i ~}$ complementar. Disciplina no Código Tributário Nacional. Recorrente: União. Recorrido: REDG - Consultoria Tributária Sociedade Civil LTDA. Relator: Min. Gilmar Mendes, 12 de junho de 2008. Disponível em:

http://redir.stf.jus.br/paginadorpub/paginador.jsp?docTP=AC\&docID $=567931$. Acesso em: 12 mar. 2020.

CANOTILHO, J. J. Gomes. Direito Constitucional. Coimbra: Almedina, 1993.

CANOTILHO, J. J. Direito Constitucional e Teoria da Constituição. 7. ed. Coimbra: Almedina, 2003.

COELHO, Inocêncio Mártires. Interpretação Constitucional. 3. ed. São Paulo: Saraiva, 2007.

GRAU, E. R. Ensaio e Discurso sobre a Interpretação: Aplicação do Direito. $3^{a}$ ed. São Paulo: Malheiros, 2005.

HÄBERLE, P. El Estado Constitucional. México: UNAM, 2001.

LENZA, P. Direito Constitucional Esquematizado. 16. ed. São Paulo: Saraiva, 2012.

MENDES, G. F.; COELHO, I. M.; BRANCO, P. G. G. Curso de Direito Constitucional. 5. ed. São Paulo: Saraiva, 2010.

NOVELINO, M. Direito Constitucional. 3. ed. São Paulo: Método, 2009.

OLIVEIRA, J. A. de. Teoria da Constituição. São Paulo: Resenha Universitária, 1979. 
SCHIER, P. R. Filtragem Constitucional: Construindo uma Nova Dogmática Jurídica. Porto Alegre: Sergio Antonio Fabris, 1999.

TEMER, M. Elementos de Direito Constitucional. 5. ed. São Paulo: Revista dos Tribunais, 1989.

Recebido em 29/03/2020.

Aceito em 07/04/2020. 